Portland State University

PDXScholar

Chemistry Faculty Publications and

Presentations

Chemistry

$12-2001$

\title{
Space-Group Revision for 4-Formylphenylboronic Acid
}

Frank R. Fronczek

Louisiana State University

Nadia N. St Luce

Louisiana State University

Robert M. Strongin

Portland State University, strongin@pdx.edu

Follow this and additional works at: https://pdxscholar.library.pdx.edu/chem_fac

Part of the Chemistry Commons

Let us know how access to this document benefits you.

Citation Details

Fronczek, F., St Luce, N., \& Strongin, R. (2001). Space-group revision for 4-formylphenylboronic acid. Acta Crystallographica. Section C, Crystal Structure Communications, 57(Pt 12), 1423-1425.

This Article is brought to you for free and open access. It has been accepted for inclusion in Chemistry Faculty Publications and Presentations by an authorized administrator of PDXScholar. Please contact us if we can make this document more accessible: pdxscholar@pdx.edu. 


\title{
Space-group revision for 4-formylphenylboronic acid
}

\author{
Frank R. Fronczek, Nadia N. St Luce and Robert M. Strongin
}

Acta Cryst. (2001). C57, 1423-1425

Copyright (C) International Union of Crystallography

Author(s) of this paper may load this reprint on their own web site or institutional repository provided that this cover page is retained. Republication of this article or its storage in electronic databases other than as specified above is not permitted without prior permission in writing from the IUCr.

For further information see http://journals.iucr.org/services/authorrights.html

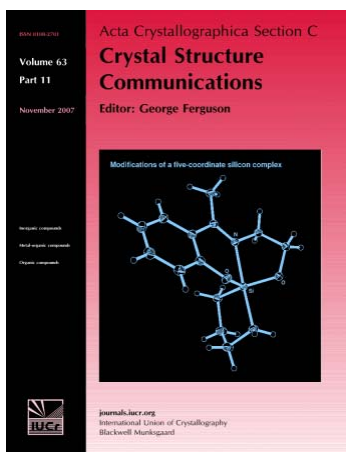

Acta Crystallographica Section C: Structural Chemistry specializes in the rapid dissemination of high-quality detailed studies of novel and challenging crystal and molecular structures of interest in the fields of chemistry, biochemistry, mineralogy, pharmacology, physics and materials science. The unique checking, editing and publishing facilities of the journal ensure the highest standards of structural reliability and presentation, while providing for reports on studies involving special techniques or difficult crystalline materials. Papers go beyond reporting the principal numerical and geometrical data, and may include the discussion of multiple related structures, a detailed description of non-routine structure determinations, placing the structure in an interesting scientific, physical or chemical context, or the discussion of interesting physical properties or modes of association. Reports of difficult or challenging structures, such as cases of twinning, severe disorder, or diffuse solvent regions are welcomed, provided the presented structures are correct and the difficulties and strategies used to treat them are scientifically discussed and properly documented. Section $C$ readers have access to an extensive back archive of high-quality structural data.

\section{Crystallography Journals Online is available from journals.iucr.org}


Acta Crystallographica Section C

Crystal Structure

Communications

ISSN 0108-2701

\section{Space-group revision for 4-formyl- phenylboronic acid}

\section{Frank R. Fronczek, ${ }^{*}$ Nadia N. St Luce and Robert M. Strongin}

Department of Chemistry, Louisiana State University, Baton Rouge, LA 70803-1804 USA

Correspondence e-mail: fronz@chxray.chem.Isu.edu

Received 10 September 2001

Accepted 24 September 2001

The space group of the title compound, $\mathrm{C}_{7} \mathrm{H}_{7} \mathrm{BO}_{3}$, previously reported to be $P \overline{1}$, is properly $C c$. There is no disorder of the formyl group or in the $\mathrm{H}$ atoms of the $\mathrm{B}(\mathrm{OH})_{2}$ group. Molecules lie on approximate twofold axes and are related by approximate centers, which relate all but the formyl $\mathrm{O}$ atom and boronic acid $\mathrm{H}$ atoms. The $\mathrm{B}-\mathrm{O}$ distances are 1.363 (2) and 1.370 (2) А̊.

\section{Comment}

During the course of studying the structure and mechanism of formation of colored products in resorcinarene solutions (Davis et al., 1999; Lewis et al., 2000), the model compound (I) was investigated. Thermolysis of (I) led to the formation of the title compound, (II), and its structure was determined to ascertain its identity.

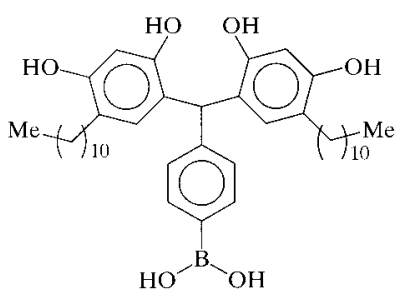

(I)

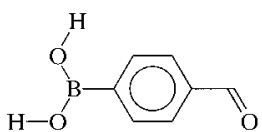

(II)
The published crystal structure of (II) (Feulner et al., 1990) is in space group $P \overline{1}$ with $Z^{\prime}=1$ at $293 \mathrm{~K}$, and has some unsettling features. In this model, the $\mathrm{CHO}$ group has a twofold disorder which superimposes its $\mathrm{C}-\mathrm{H}$ and $\mathrm{C}=\mathrm{O}$ bonds. The boronic acid $\mathrm{H}$-atom positions are not sensible for the expected hydrogen bonding, and form impossibly short intermolecular $\mathrm{H} \cdots \mathrm{H}$ contacts. The model fits the data poorly $(R=0.097$ and $w R=0.181)$, despite the fact that this compound forms high quality crystals. Furthermore, the triclinic cell can be transformed $(0 \overline{11}, 01 \overline{1}, 100)$ to a $C$-centered cell with a monoclinic metric. Feulner et al. (1990) recognized this transformation, and attempted a structure solution in $C 2 / c$ with $Z^{\prime}=\frac{1}{2}$. Their reported $C$-centered cell has dimensions $a=$ $11.177(5), b=9.891$ (4) and $c=7.339$ (4) $\AA$, and $\beta=$ $118.37(3)^{\circ}$. (Note: transformation of their triclinic cell yields $\beta=119.11^{\circ}$, which more closely matches our value.) Their model, deposited as the 'monoclinic form' (refcode VEXFUZ01) in the Cambridge Structural Database (Allen \& Kennard, 1993) has the molecule on a twofold axis, which requires a similar disorder in the formyl group. This model produced worse $R$ values ( $R=0.145$ and $w R=0.151)$. Despite intensity statistics suggesting a centrosymmetric structure, Feulner et al. (1990) also attempted structure solution in space group $C c$, but were unsuccessful for reasons which are unclear.

Our structure of (II), with $Z^{\prime}=1$ in space group $C c$ (Fig. 1), exhibits none of these troubling features. The formyl group is ordered, and the $\mathrm{H}$ atoms of the $\mathrm{B}(\mathrm{OH})_{2}$ group are ordered and in sensible positions for intermolecular hydrogen bonds (Table 2). The packing (Fig. 2) exhibits a pseudocenter near $\left(\frac{1}{2}, \frac{1}{2}, \frac{1}{2}\right)$ and a pseudo-twofold axis near $\left(\frac{1}{2}, y, \frac{3}{4}\right)$, running along the long axis of the molecule. The two molecules near the center of the cell are related by the $c$ glide, and are approximately related by the pseudocenter. Treating the center as exact rather than the glide leads to the $P \overline{1}$ model, while treating both the center and the glide as exact leads to the $C 2 / c$ model. The cause of the disordered formyl group and boronic acid $\mathrm{H}$ atoms in the $P \overline{1}$ model can be seen in Fig. 2 by examination of the relative orientations of the two gliderelated molecules about $\left(\frac{1}{2}, \frac{1}{2}, \frac{1}{2}\right)$. The formyl $\mathrm{O}$ and boronic acid $\mathrm{H}$ atoms do not conform to the inversion, while the remainder of the molecule nearly does. The pseudosymmetry does not lead to exceptionally high correlations, with the largest being 0.63 , between displacement parameters of atoms related by the approximate twofold axis.

We have ruled out the possibility that a phase change on cooling causes the difference between the $C c$ structure which we observe at $120 \mathrm{~K}$ and that reported by Feulner et al. (1990) at room temperature. Using the same crystal, we collected intensity data at $296 \mathrm{~K}$ and obtained the same $C c$ structure, with cell dimensions $a=11.1932$ (4), $b=9.8820$ (5) and $c=$ 7.3373 (3) $\AA, \beta=119.336$ (3) $)^{\circ}$ and $R=0.043$. Using this data set, we were also able to reproduce the results of Feulner et al. (1990), refining their $P \overline{1}$ model to $R=0.099$.

The structure of the molecule itself is unremarkable. The formyl group is essentially coplanar with the phenyl ring, while the $\mathrm{B}(\mathrm{OH})_{2}$ group is rotated by $20.6(3)^{\circ}$ out of the phenyl plane. One hydroxyl $\mathrm{H}$ atom is syn to the phenyl group, while the other is anti, as is typical for phenylboronic acids (Bradley et al., 1996; Gainsford et al., 1995; Pilkington et al., 1995; Shull



Figure 1

A view of the molecule of (II) with the atom-numbering scheme and displacement ellipsoids at the $50 \%$ probability level. $\mathrm{H}$ atoms are shown as small spheres of arbitrary radii. 
et al., 2000; Soundararajan et al., 1993), including unsubstituted phenylboronic acid (Rettig \& Trotter, 1977) and the ortho isomer of the title compound (Scouten et al., 1994).

Baur \& Kassner (1992) and Marsh (1997) have warned of the perils of space group $C c$. In the present structure, more
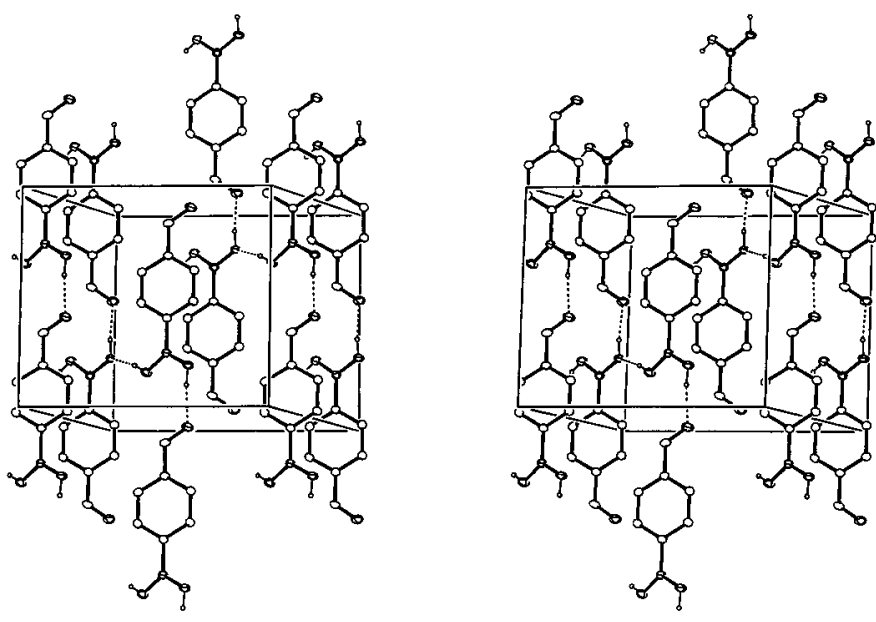

Figure 2

A stereoview of the unit cell of (II), illustrating the hydrogen bonding and pseudosymmetry. The $a$ axis is horizontal and the $b$ axis is vertical.

perilous is the imposition of centrosymmetry on the basis of centric intensity statistics. From our data, a chemically correct structure, albeit unnecessarily low symmetry, may be easily obtained in space group $P 1$. However, no chemically correct model can be obtained in any centrosymmetric space group.

\section{Experimental}

The preparation of the title compound has been previously described by Feulner et al. (1990). In our preparation, compound (I) (300 mg, $0.448 \mathrm{mmol})$, dimethyl sulfoxide (DMSO, $27 \mathrm{ml})$, and water $(3 \mathrm{ml})$ were mixed and heated for $5 \mathrm{~d}$ at $493 \mathrm{~K}$ in a sealed tube. The reaction mixture was cooled, filtered, and $\mathrm{DMSO} / \mathrm{H}_{2} \mathrm{O}$ was removed in vacuo. The yellowish substance obtained was washed with ethyl acetate (EtOAc) and upon drying afforded colorless crystals of the title compound $(0.210 \mathrm{~g})$ in $72 \%$ yield. Diffraction-quality crystals of (II) were grown by evaporation of an EtOAc solution.

\section{Crystal data}

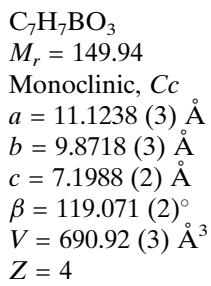

$$
\begin{aligned}
& D_{x}=1.441 \mathrm{Mg} \mathrm{m}^{-3} \\
& \text { Mo } K \alpha \text { radiation } \\
& \text { Cell parameters from } 1107 \\
& \quad \text { reflections } \\
& \theta=2.5-32.0^{\circ} \\
& \mu=0.11 \mathrm{~mm}^{-1} \\
& T=120 \mathrm{~K} \\
& \text { Lath fragment, colorless } \\
& 0.37 \times 0.25 \times 0.22 \mathrm{~mm}
\end{aligned}
$$

\section{Data collection}

$\begin{array}{ll}\text { Nonius KappaCCD area-detector } & 1110 \text { reflections with } I>2 \sigma(I) \\ \quad \text { diffractometer (with an Oxford } & R_{\text {int }}=0.021 \\ \text { Cryosystems Cryostream cooler) } & \theta_{\max }=32^{\circ} \\ \omega \text { scans with } \kappa \text { offsets } & h=-15 \rightarrow 16 \\ 4518 \text { measured reflections } & k=-14 \rightarrow 14 \\ 1192 \text { independent reflections } & l=-10 \rightarrow 10\end{array}$

\section{Refinement}

$$
\begin{aligned}
& \text { Refinement on } F^{2} \\
& R\left[F^{2}>2 \sigma\left(F^{2}\right)\right]=0.038 \\
& w R\left(F^{2}\right)=0.104 \\
& S=1.07 \\
& 1192 \text { reflections } \\
& 106 \text { parameters } \\
& \text { H atoms treated by a mixture of } \\
& \quad \text { independent and constrained } \\
& \quad \text { refinement }
\end{aligned}
$$

$$
\begin{gathered}
w=1 /\left[\sigma^{2}\left(F_{o}^{2}\right)+(0.0689 P)^{2}\right. \\
\quad+0.1001 P] \\
\text { where } P=\left(F_{o}^{2}+2 F_{c}^{2}\right) / 3 \\
(\Delta / \sigma)_{\max }<0.001 \\
\Delta \rho_{\max }=0.44 \mathrm{e} \AA^{-3} \\
\Delta \rho_{\min }=-0.22 \AA^{-3}
\end{gathered}
$$

Table 1

Selected geometric parameters $\left(\AA,^{\circ}\right)$.

\begin{tabular}{llll}
\hline $\mathrm{O} 1-\mathrm{C} 7$ & $1.222(2)$ & $\mathrm{O} 3-\mathrm{B} 1$ & $1.363(2)$ \\
$\mathrm{O} 2-\mathrm{B} 1$ & $1.370(2)$ & $\mathrm{B} 1-\mathrm{C} 1$ & $1.5724(17)$ \\
& & & \\
$\mathrm{O} 3-\mathrm{B} 1-\mathrm{O} 2$ & $117.70(11)$ & $\mathrm{O} 2-\mathrm{B} 1-\mathrm{C} 1$ & $118.21(15)$ \\
$\mathrm{O} 3-\mathrm{B} 1-\mathrm{C} 1$ & $124.09(16)$ & $\mathrm{O} 1-\mathrm{C} 7-\mathrm{C} 4$ & $123.21(19)$ \\
& & & \\
$\mathrm{O} 3-\mathrm{B} 1-\mathrm{C} 1-\mathrm{C} 2$ & $-20.6(3)$ & $\mathrm{C} 5-\mathrm{C} 4-\mathrm{C} 7-\mathrm{O} 1$ & $-1.8(4)$ \\
\hline
\end{tabular}

Table 2

Hydrogen-bonding geometry $\left(\AA{ }^{\circ}\right)$.

\begin{tabular}{lllll}
\hline$D-\mathrm{H} \cdots A$ & $D-\mathrm{H}$ & $\mathrm{H} \cdots A$ & $D \cdots A$ & $D-\mathrm{H} \cdots A$ \\
\hline $\mathrm{O} 2-\mathrm{H} 2 \mathrm{O} \cdots \mathrm{O} 1^{\mathrm{i}}$ & $0.87(3)$ & $1.86(3)$ & $2.7209(16)$ & $171(3)$ \\
$\mathrm{O} 3-\mathrm{H} 3 \mathrm{O} \cdots \mathrm{O} 2^{\mathrm{ii}}$ & $0.83(3)$ & $2.02(3)$ & $2.8321(13)$ & $165(3)$ \\
\hline
\end{tabular}

Symmetry codes: (i) $x, 1+y, z$; (ii) $\frac{1}{2}+x, \frac{3}{2}-y, \frac{1}{2}+z$.

Systematic absences indicated space group $C c$ or $C 2 / c$. Although intensity statistics suggested $C 2 / c\left(\left|E^{2}-1\right|=0.992\right)$, the non-centrosymmetric space group $C c$ proved correct. The absolute structure could not be determined. The coordinates of the hydroxyl $\mathrm{H}$ atoms were refined. Other $\mathrm{H}$ atoms were treated as riding in idealized positions, with $\mathrm{C}-\mathrm{H}$ distances of $0.95 \AA$. Displacement parameters for $\mathrm{H}$ atoms were assigned as $U_{\text {iso }}=1.2 U_{\text {eq }}$ of the attached atom (1.5 $U_{\text {eq }}$ for hydroxy $\mathrm{H}$ atoms).

Data collection: COLLECT (Nonius, 2000); cell refinement: $D E N Z O$ and SCALEPACK (Otwinowski \& Minor, 1997); data reduction: $D E N Z O$ and $S C A L E P A C K$; $\operatorname{program}(\mathrm{s})$ used to solve structure: SIR97 (Altomare et al., 1999); program(s) used to refine structure: SHELXL97 (Sheldrick, 1997); molecular graphics: ORTEP-3 (Farrugia, 1997); software used to prepare material for publication: SHELXL97.

The purchase of the diffractometer was made possible by grant No. LEQSF(1999-2000)-ESH-TR-13, administered by the Louisiana Board of Regents. We are grateful to Professor Steven F. Watkins for helpful comments.

Supplementary data for this paper are available from the IUCr electronic archives (Reference: DA1214). Services for accessing these data are described at the back of the journal.

\section{References}

Allen, F. H. \& Kennard, O. (1993). Chem. Des. Autom. News, 8, 1, 31-37. 
Altomare, A., Burla, M. C., Camalli, M., Cascarano, G., Giacovazzo, C., Guagliardi, A., Moliterni, A. G. G., Polidori, G. \& Spagna, R. (1999). J. Appl. Cryst. 32, 115-119.

Baur, W. H. \& Kassner, D. (1992). Acta Cryst. B48, 356-357.

Bradley, D. C., Harding, I. S., Keefe, A. D., Motevalli, M. \& Zheng, D. H. (1996). J. Chem. Soc. Dalton Trans. pp. 3931-3936.

Davis, C. J., Lewis, P. T., McCarroll, M. E., Reed, M. W., Cueto, R. \& Strongin, R. M. (1999). Org. Lett. 1, 331-334.

Farrugia, L. J. (1997). J. Appl. Cryst. 30, 565.

Feulner, H., Linti, G. \& Nöth, H. (1990). Chem. Ber. 123, 1841-1843.

Gainsford, G. J., Meinhold, R. H. \& Woolhouse, A. D. (1995). Acta Cryst. C51, 2694-2696.

Lewis, P. T., Davis, C. J., Cabell, L. A., He, M., Read, M. W., McCarroll, M. E. \& Strongin, R. M. (2000). Org. Lett. 2, 589-592.

Marsh, R. E. (1997). Acta Cryst. B53, 317-322.
Nonius (2000). COLLECT. Nonius BV, Delft, The Netherlands.

Otwinowski, Z. \& Minor, W. (1997). Methods in Enzymology, Vol. 276, Macromolecular Crystallography, Part A, edited by C. W. Carter \& R. M. Sweet, pp. 307-326. London: Academic Press.

Pilkington, M., Wallis, J. D. \& Larsen, S. (1995). J. Chem. Soc. Chem. Commun. pp. $1499-1500$.

Rettig, S. J. \& Trotter, J. (1977). Can. J. Chem. 55, 3071-3075.

Scouten, W. H., Liu, X.-C., Khangin, N., Mullica, D. F. \& Sappenfield, E. L. (1994). J. Chem. Crystallogr. 24, 621-626.

Sheldrick, G. (1997). SHELXL97. University of Göttingen, Germany.

Shull, B. K., Spielvogel, D. E., Gopalaswamy, R., Sankar, S., Boyle, P. D., Head, G. \& Devito, K. (2000). J. Chem. Soc. Perkin Trans. 2, pp. 557561.

Soundararajan, S., Duesler, E. N. \& Hageman, J. H. (1993). Acta Cryst. C49, 690-693. 